\title{
FARAÓN-INIA, A NEW WINTER TRITICALE (xTriticosecale Wittmack) FOR SOUTHERN CHILE
}

\author{
Claudio Jobet ${ }^{1 *}$, Iván Matus ${ }^{2}$, Ricardo Campillo ${ }^{1}$, Oriela Romero ${ }^{1}$, Ricardo Madariaga ${ }^{2}$, and Cristian \\ Alfaro ${ }^{1}$
}

\begin{abstract}
Faraón-INIA is a new winter triticale ( $\times$ Triticosecale Wittmack) cultivar released by the National Wheat Program of the Instituto de Investigaciones Agropecuarias INIA in Chile. It is derived from an F9 material received from Nordsaat, Germany, under a germplasm exchange agreement signed in 2006 by both institutions. The crossing was Piano/Focus with Nord 93.7548 pedigree. Faraón-INIA has a winter growth habit, a short stem (semi-dwarf), with a mean height of $106 \mathrm{~cm}$. The spike is long, compact, decumbent, white, and awned. The grain is soft, yellow, with 1000-grain weight of $36 \mathrm{~g}$, and a mean of hectoliter weight of $76 \mathrm{~kg} \mathrm{hL}^{-1}$. It is resistant to stripe rust (Puccinia striiformis West. f. sp. tritici) and leaf rust (Puccinia triticina Erikss.) as well as moderately resistant to septoria leaf blotch. Its mean yield for four seasons in three different locations: Temuco $\left(38^{\circ} 50^{\prime} \mathrm{S}, 72^{\circ} 25^{\prime} \mathrm{W}\right)$, Traiguén (38 $45^{\prime}$ S, 72 $38^{\prime} \mathrm{W}$ ), and Purranque (36 $31^{\prime} \mathrm{S}, 71^{\circ} 54^{\prime} \mathrm{W}$ ) varied between 8.2 and $15.0 \mathrm{t}$ ha ${ }^{-1}$ with a general mean of $11.0 \mathrm{t}$ $\mathrm{ha}^{-1}$. Bromatological analysis of the grain showed good protein content $(10.6 \%)$ and a generally better quality than other triticale cultivars. Based on the above information, Faraón-INIA is recommended for use as animal feed in Southern Chile.
\end{abstract}

Key words: winter triticale, high-yielding cultivar, quality, Triticosecale.

\section{INTRODUCTION}

Triticale ( $\times$ Triticosecale Wittmack) is a self-pollinating cereal which is artificially produced by crossing wheat (Triticum spp.) and rye (Secale cereale L.) After more than $100 \mathrm{yr}$ of research of this species the improvement and agronomic management have been very important (Varughese et al., 1987; Mellado et al., 2008). Studies in triticale started in Chile in 1970 when experimental lines from Mexico (Centro Internacional de Mejoramiento de Maíz y Trigo, CIMMYT) through the Sociedad Nacional de Agricultura (Mayorga, 1971) were introduced and tested. Then, the Pontificia Universidad Católica (Parodi and Nebreda, 1982), the Instituto de Investigaciones Agropecuarias INIA (Hewstone, 1990), and Semillas Baer begin genetics and crop management research studies of this cereal. New triticale cultivars currently have a grain similar to wheat, good agronomic characteristic plants, resistant to lodging, and wide adapted so that it

${ }^{1}$ Instituto de Investigaciones Agropecuarias INIA, casilla 58-D, Temuco, Chile. *Corresponding author (cjobet@inia.cl).

${ }^{2}$ Instituto de Investigaciones Agropecuarias INIA, casilla 426, Chillán, Chile.

Received: 11 September 2009.

Accepted: 14 January 2010. is possible to sow them in different parts of the country. In fact, the major planting area in Chile is concentrated in the La Araucanía Region (INE, 2010). The National Wheat Program of INIA, as a way to enhance this crop in the country, has developed triticale cultivars adapted to the southern zone for more than $25 \mathrm{yr}$. The new cultivar Faraón-INIA offers a new alternative for winter sowing.

\section{ORIGIN, CROSSING, AND PEDIGREE}

Faraón-INIA is derived from an $\mathrm{F}_{9}$ material received from Nordsaat, Germany, under a germplasm exchange agreement signed in 2006 by both institutions. The crossing was Piano/Focus with Nord 93.7548 pedigree. Faraón-INIA has been evaluated in yield trials in INIA Carillanca, Temuco $\left(38^{\circ} 50^{\prime} \mathrm{S}, 72^{\circ} 25^{\prime} \mathrm{W}\right.$ ) since 2005 2006 season, as well as in different locations such as Traiguén $\left(38^{\circ} 45^{\prime} \mathrm{S}, 72^{\circ} 38^{\prime} \mathrm{W}\right)$ and Purranque (36 $31^{\prime} \mathrm{S}$, $\left.71^{\circ} 54^{\prime} \mathrm{W}\right)$.

\section{MORPHOLOGICAL DESCRIPTION OF THE PLANT}

Faraón-INIA has a winter growth habit, a short stem (semi-dwarf), with a mean height of $106 \mathrm{~cm}$ shorter 
than the spring var. Aguacero-INIA $(115 \mathrm{~cm})$, the facultative var. Lonko BAER $(132 \mathrm{~cm})$, and similar to the facultative var. Peteroa-INIA $(105 \mathrm{~cm})$. The spike is long, compact, decumbent, white, and with awns along its full length. The grain is soft, yellow, with a 1000 grains weight of $36 \mathrm{~g}$, and an average of hectoliter weight of $76 \mathrm{~kg} \mathrm{hL}^{-1}$.

\section{AGRONOMIC CHARACTERISTICS}

Faraón-INIA has a medium-length stem with an acceptable resistance to lodging. In Temuco (INIA Carillanca) its vegetative period from sowing to heading is 10 to $12 \mathrm{~d}$ later than var. Peteroa-INIA. When it is sown in Carillanca on 14 May, heading occurs between 10 and 14 of November (approximately 176 to $180 \mathrm{~d}$ from sowing to heading). In Purranque sowed on 23 May, heading occurs around 2 December (approximately 189 $\mathrm{d}$ from sowing to heading) which is around 4 to $6 \mathrm{~d}$ later than Peteroa-INIA and Lonko BAER. Considering that this triticale requires vernalization must be recommended for early autumn and winter sowing in South Central and Southern Chile.

\section{PHYTOPATHOLOGICAL CHARACTERISTICS}

Faraón-INIA is resistant to stripe rust (Puccinia striiformis West. f. sp. tritici) and leaf rust (Puccinia triticina Erikss.) according to Cobb's modified scale (Peterson et al., 1984; Stubbs et al., 1986), as well as moderately resistant to septoria leaf blotch (Mycosphaerella graminicola (Fuckel) J. Schröt.) according to the Saari and Prescott double digit scale (1975) (Tottman and Makepeace, 1979), and is resistant to powdery mildew caused by the
Blumeria graminis D.C. f. sp. tritici Marchal fungus. It is also tolerant to leaf scald (Rhynchosporium secalis (Dudd) J.J. Davis), a disease affecting leaves of some triticales (Madariaga and Mellado, 1992).

\section{GRAIN YIELD}

In yield trials carried out from Traiguén to Purranque under different agroclimatic conditions, Faraón-INIA has shown a stable yield, higher than commercial vars. Lonko-BAER and Peteroa-INIA. The mean yield in three locations during $4 \mathrm{yr}$ evaluation was $11.0 \mathrm{t} \mathrm{ha}^{-1}$, which is higher than Peteroa-INIA and Lonko-BAER, respectively. The biggest difference between FaraónINIA and these varieties was obtained in Purranque where it exceeded yields of $15 \mathrm{t} \mathrm{ha}^{-1}$ in all three seasons (Table 1).

\section{QUALITY AND USES}

Faraón-INIA is a triticale with acceptable hectoliter weight $\left(74.8 \mathrm{~kg} \mathrm{hL}^{-1}\right)$, similar to Peteroa-INIA $(73.8 \mathrm{~kg}$ $\mathrm{hL}^{-1}$ ), but lower than Lonko-BAER (76.4 $\mathrm{kg} \mathrm{hL}^{-1}$ ) for values observed in the four seasons and three locations (Table 2). Its grain protein percentage is higher than $10.0 \%$, dry matter digestibility over $95.0 \%$, metabolizable energy higher than $3.3 \mathrm{Mcal} \mathrm{kg}^{-1}$, and $1.9 \%$ crude fiber (Table 3). Grain bromatological analysis showed good protein content $(10.6 \%)$ and a generally better quality than other triticale cultivars. Based on the above information, Faraón-INIA is recommended for use as animal feed in Southern Chile.

Table 1. Mean grain yield of var. Faraón-INIA compared to Peteroa-INIA and Lonko-BAER in three locations over four seasons (2005-2006 to 2008-2009).

\begin{tabular}{|c|c|c|c|c|c|c|}
\hline \multirow[b]{2}{*}{ Location } & \multirow[b]{2}{*}{ Variety } & \multicolumn{4}{|c|}{ Crop seasons } & \multirow[b]{2}{*}{ Mean } \\
\hline & & $2005-2006$ & 2006-2007 & 2007-2008 & 2008-2009 & \\
\hline & & & - & - $\mathrm{tha}^{-1}$ & & 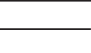 \\
\hline \multirow[t]{3}{*}{ Traiguén } & Faraón-INIA & $7.3 \mathrm{a}$ & $7.6 \mathrm{a}$ & $8.9 \mathrm{a}$ & $9.0 \mathrm{a}$ & 8.2 \\
\hline & Peteroa-INIA & $6.2 b$ & $4.7 b$ & $5.9 \mathrm{~b}$ & $4.9 \mathrm{c}$ & 5.4 \\
\hline & Lonko BAER & $6.4 b$ & $4.9 \mathrm{~b}$ & $4.5 b$ & $6.5 b$ & 5.6 \\
\hline \multirow[t]{3}{*}{ Temuco } & Faraón-INIA & $9.6 \mathrm{a}$ & $11.5 \mathrm{a}$ & $10.1 \mathrm{a}$ & $7.5 \mathrm{a}$ & 9.7 \\
\hline & Peteroa-INIA & $7.5 b$ & $8.5 b$ & $8.4 \mathrm{~b}$ & $5.5 \mathrm{~b}$ & 7.5 \\
\hline & Lonko BAER & $8.2 \mathrm{~b}$ & $7.3 b$ & $3.9 \mathrm{c}$ & $6.6 \mathrm{~b}$ & 6.5 \\
\hline \multirow[t]{3}{*}{ Purranque } & Faraón-INIA & $16.6 \mathrm{a}$ & $15.9 \mathrm{a}$ & $16.9 \mathrm{a}$ & $10.7 \mathrm{a}$ & 15.0 \\
\hline & Peteroa-INIA & $14.5 b$ & $12.7 \mathrm{~b}$ & $13.5 b$ & $10.5 \mathrm{a}$ & 12.8 \\
\hline & Lonko-BAER & $9.4 \mathrm{c}$ & $8.3 \mathrm{c}$ & $10.6 \mathrm{c}$ & $10.3 \mathrm{a}$ & 9.7 \\
\hline
\end{tabular}

Different letters in columns and for each location indicate differences according to Tukey test $(\mathrm{P}<0.05)$. 
Table 2. Mean hectoliter weight of var. Faraón-INIA compared to Peteroa-INIA in three locations over four seasons (2005-2006 to 2008-2009).

\begin{tabular}{|c|c|c|c|c|c|c|}
\hline \multirow[b]{2}{*}{ Location } & \multirow[b]{2}{*}{ Variety } & \multicolumn{4}{|c|}{ Crop seasons } & \multirow[b]{2}{*}{ Mean } \\
\hline & & $2005-2006$ & 2006-2007 & 2007-2008 & 2008-2009 & \\
\hline & & & & $-\mathrm{Kg} \mathrm{hL}^{-1}$ & & 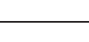 \\
\hline \multirow[t]{3}{*}{ Traiguén } & Faraón-INIA & $76.8 \mathrm{a}$ & $75.4 \mathrm{a}$ & $76.1 \mathrm{a}$ & $76.1 \mathrm{a}$ & 76.1 \\
\hline & Peteroa-INIA & $74.5 b$ & $73.5 \mathrm{a}$ & $74.0 \mathrm{a}$ & $74.0 \mathrm{~b}$ & 74.0 \\
\hline & Lonko BAER & $77.1 \mathrm{a}$ & $76.8 \mathrm{a}$ & $74.5 \mathrm{a}$ & $76.5 \mathrm{a}$ & 76.2 \\
\hline \multirow[t]{3}{*}{ Carillanca } & Faraón-INIA & $72.7 \mathrm{a}$ & $75.7 b$ & $75.5 b$ & $75.5 \mathrm{a}$ & 74.9 \\
\hline & Peteroa-INIA & $70.3 \mathrm{a}$ & $77.7 \mathrm{a}$ & $75.3 b$ & $74.3 \mathrm{a}$ & 74.4 \\
\hline & Lonko BAER & $73.4 \mathrm{a}$ & $78.9 \mathrm{a}$ & $77.6 \mathrm{a}$ & $75.2 \mathrm{a}$ & 76.2 \\
\hline \multirow[t]{3}{*}{ Purranque } & Faraón-INIA & $70.2 b$ & $72.9 b$ & $75.5 \mathrm{a}$ & $74.5 b$ & 73.3 \\
\hline & Peteroa-INIA & $72.8 b$ & $74.3 b$ & $73.2 b$ & $72.2 b$ & 73.1 \\
\hline & Lonko BAER & $76.5 \mathrm{a}$ & $78.5 \mathrm{a}$ & $76.4 b$ & $76.2 \mathrm{a}$ & 76.9 \\
\hline
\end{tabular}

Different letters in columns and for each location indicate differences according to Tukey test $(\mathrm{P}<0.05)$.

Table 3. Quality characteristics of triticale var. Faraón-INIA compared to three commercial varieties. Mean of two locations (Temuco and Purranque) and two seasons (2006-2007 and 2007-2008).

\begin{tabular}{|c|c|c|c|c|}
\hline Parameters $^{*}$ & Faraón-INIA & Aguacero-INIA & Peteroa-INIA & Lonko-BAER \\
\hline Dry matter ${ }^{1}, \%$ & 85.60 & 86.60 & 86.30 & 86.40 \\
\hline Ash, \% & 1.60 & 1.70 & 1.90 & 1.60 \\
\hline Total proteins ${ }^{2}, \%(\mathrm{~N}$ x 6.25) & 10.60 & 13.50 & 13.00 & 10.80 \\
\hline Dry matter digestibility ${ }^{3}, \%$ & 95.30 & 93.70 & 93.60 & 93.20 \\
\hline Digestibility $^{4}, \%$ & 93.50 & 91.60 & 91.40 & 91.10 \\
\hline Metabolizable energy5, Mcal kg-1 & 3.32 & 3.26 & 3.25 & 3.24 \\
\hline Crude fiber ${ }^{6}, \%$ & 1.90 & 2.60 & 2.30 & 2.60 \\
\hline Neutral detergent fiber ${ }^{7}, \%$ & 14.10 & 15.40 & 14.20 & 15.30 \\
\hline Ether extract ${ }^{8}, \%$ & 0.90 & 1.30 & 1.50 & 1.50 \\
\hline Non-structural carbon ${ }^{9}, \%$ & 71.10 & 65.60 & 67.20 & 68.60 \\
\hline Wet gluten ${ }^{10}, \%$ & 10.30 & 21.00 & 20.00 & - \\
\hline
\end{tabular}

*Mean values (Bromatology Laboratory, INIA Remehue).

${ }^{6}$ Values $<2 \%$ correspond to a good value.

${ }^{7}$ Values $>12 \%$ correspond to a good value.

${ }^{8}$ Values $<1 \%$ correspond to a good value.

${ }^{9}$ Values $>70 \%$ correspond to a good value.

${ }^{2}$ Values $>12 \%$ correspond to a good value.

${ }^{3}$ Values $>90 \%$ correspond to a good value.

${ }^{4}$ Values $>90 \%$ correspond to a good value.

${ }^{5}$ Values $>3.0 \%$ correspond to a good value.

${ }^{10}$ Values $<20 \%$ correspond to a good value (considering triticale for animal feed).

\section{CULTIVATION AREA AND SOWING DATES}

Faraón-INIA is recommended for locations between the La Araucanía and Los Lagos Regions, including Los Ríos Region. Due to its long vegetative cycle, early sowing from April to May is recommended even though it has good development and adequate spike production when sown until the end of June from Temuco southward.

\section{RESUMEN}

Faraón-INIA, un nuevo triticale de invierno (xTriticosecale Wittmack) para el sur de Chile. FaraónINIA es un nuevo cultivar de triticale ( $\times$ Triticosecale Wittmack) liberado por el Programa Nacional de Trigo del Instituto de Investigaciones Agropecuarias INIA, Chile. Este cultivar deriva de un material $\mathrm{F}_{9}$ recibido de la empresa Nordsaat, Alemania, bajo un convenio formal firmado en el 2006 entre ambas instituciones. La cruza es Piano/Focus, y el pedigrí Nord-93.7548. Faraón- 
INIA tiene un hábito de desarrollo invernal y caña corta (semienano), con un promedio de altura de $106 \mathrm{~cm}$. La espiga es larga, compacta, decumbente, blanca y barbada. El grano es blando, amarillo, con un peso de 100 granos de $36 \mathrm{~g}$ y un promedio de $76 \mathrm{~kg} \mathrm{hL}^{-1}$ de peso del hectolitro. Es resistente a roya estriada (Puccinia striiformis West. $f$. sp. tritici) y roya colorada de la hoja (Puccinia triticina Erikss.) y moderadamente resistente a septoria leaf blotch. Su rendimiento promedio para cuatro temporadas varió entre 8.2 y $15.0 \mathrm{t} \mathrm{ha}^{-1}$ en tres localidades diferentes: Temuco ( $38^{\circ} 50^{\prime} \mathrm{S}, 72^{\circ} 25^{\prime} \mathrm{O}$ ), Traiguén ( $38^{\circ} 45^{\prime} \mathrm{S}, 72^{\circ} 38^{\prime}$ O) y Purranque $\left(36^{\circ} 31^{\prime} \mathrm{S}, 71^{\circ} 54^{\prime} \mathrm{O}\right)$, con un promedio general de 11,0 t ha-1. El análisis bromatológico de los granos mostró buen contenido de proteína (10.6\%) y en general mejor calidad que otras variedades de triticale. Sobre la base de lo anterior, Faraón-INIA se recomienda para ser utilizado en la alimentación animal en el Sur de Chile.

Palabras clave: triticale invernal, cultivar de alto rendimiento, calidad, Triticosecale.

\section{LITERATURE CITED}

Hewstone, M. 1990. Triticale investigation in Chile. p. 586-592. In Proceeding of the Second International Triticale Symposium, Passo Fundo, Río Grande do Sul, Brasil. 1-5 October. CIMMYT, EMBRAPACNPT, ITA, México.

INE, 2010. Cultivos anuales esenciales, superficie, producción y rendimientos, según región. Año agrícola 2009/2010. Available at http://www.odepa. minagri.gob.cl (accessed 8 September 2010).
Madariaga, R., y M. Mellado. 1992. El escaldado del triticale en Chile. Agricultura Técnica 50:225-228.

Mayorga, I. 1971. Triticales en Chile. Simiente 41(34):52-53

Mellado, M., I. Matus, y M. Madariaga, 2008. Antecedentes sobre el triticale en Chile y otros países. Boletín $\mathrm{N}^{\circ}$ 183. 74 p. Instituto de Investigaciones Agropecuarias INIA, Chillán, Chile.

Parodi, P., e I. Nebreda. 1982. Seis años de investigación en triticale ( $\times$ Triticosecale Wittmack) en Chile. Ciencia e Investigación Agraria 9:15-25.

Peterson, R., J. Campbell, and A. Hannah. 1984. A diagrammatic scale for estimating rust intensity of leaves and stem of cereals. Canadian Journal of Research Section C-Botanical Series 26:496-500.

Saari, E., and J.M. Prescott. 1975. A scale for appraising the foliar intensity of wheat diseases. Plant Disease Reporter 59:377-380.

Stubbs, R., J.M. Prescott, E. Saari, and H.J. Dubin. 1986. Cereal disease methodology manual. 46 p. Centro Internacional de Mejoramiento de Maíz y Trigo (CIMMYT), México.

Tottman, D., and R. Makepeace. 1979. An explanation of the decimal code for the growth stages of cereals, with illustrations. Annals of Applied Biology 93:221-234.

Varughese, G., T. Barker, and E. Saari. 1987. Triticale. 32 p. Centro Internacional de Maíz y Trigo (CIMMYT), México. 